\title{
ARTISTICALLY TALENTED AND ACADEMICALLY GIFTED IUNIOR HIGH STUDENTS: A COMPARATIVE STUDY OF THEIR BACKGROUNDS, INTERESTS AND AMBITIONS
}

\section{Charles Gareri}

My interests in the differences between artistically talented students and academically gifted students began after reading a statement in Louise Yochim's book, Perceptual Growth in Creativity (1967), that talented art students do well in science, social studies, and language arts. She did state, however, they do not do well in mathematics or other curriculum areas that require math skills.

I tried to find more research that could support such a statement, or give information as to differences between artistically talented and academically gifted students. I found very little information. I did, however, find a very interesting study that was done in 1938 by Glenn Myers Blair, who was an instructor in educational psychology at the University of Illinois. His study compared the backgrounds, interests, and ambitions of mentally "superior and inferior" children in the junior and senior high school.

In this paper I will outline Blair's study and present a contemporary study based on his original research. First, I will make a brief statement about the work that was summarized by Blair.

Blair reports that the most notable work done in the area of gifted students was carried out by Leta Hollingworth in 1926 at Teachers College, Columbia University, and Lewis Terman beginning in 1921 at Stanford University, for his research about superior and inferior students. Hollingworth was the author of several books that helped pioneer the field of gifted/talented studies. Both Hollingworth and Terman studied gifted elementary school aged children. Their method was to compare children who scored in the highest percentiles of intelligence tests with a control group. Among Terman's (1925) many findings was a correlation of the high occupational levels of parents with high IQ scores of their children and the fact that high IQ was evenly distributed between males and females. Leta Hollingworth (1935) found that gifted students were taller, stronger, have fewer and brighter siblings, and possess greater facial beauty than do average students.

In Blair's study, he administered the Otis S-A, Test of Mental Ability to 3,000 junior and senior high students in Everett, Washington. Pupils whose intelligence quotients were one standard deviation or more above their respective groups mean were labeled "superior", while those pupils whose IQ's were one standard deviation or more below the mean were classified as "inferior". He then had the students in these two groups fill out a questionnaire, concerning their backgrounds, interests, and ambitions. The questionnaire asked such questions as: whether they were going on to high school or college, what school subject they liked and disliked, what occupation they expected to follow, educational levels of 
parents, what hobbies they had, what school activities they participated in, and what their reading interests were. Some thirty questions were asked on the questionnaire.

Although the Blair study was not concerned with art issues, nor were there any groups identified as talented in the arts, 1 felt the questionnaire would be very useful if it had been administered to a group of talented art students for comparison with the academic groups.

During the summer of 1983,1 was an instructor of ceramics at the Indiana University Summer Arts Institute for visually talented art students. Junior high students who have demonstrated a high degree of art talent were nominated by various criteria for the program. Since the College for Gifted Youth, a program for academically gifted junior high students, was also taking place at the same time on the Indiana University campus, I felt this would be an ideal time to administer the questionnaire to both groups.

The talented art group consisted of 64 students and the academically gifted group were 82 in number. Both groups were comprised of approximately $50 \%$ male and $50 \%$ female. My study consisted of two parts. The first was a comparison of the results from the questionnaire between the 1938 group of academically gifted students with that of the 1983 group, which was a combination of the artistically talented and academically gifted groups. I felt it would be approximately the age of the 1938 groups' grandchildren. The second part was a comparison between the 1983 group of artistically talented and the academically gifted students from both programs. I was well aware of the fact that many of the artistically talented were also perhaps academically gifted and visa-versa.

Part I

Comparisons between the 1938 group and the 1983 groups showed many differences that can be attributed to the changes in time and society, however, some rather dramatic differences were also quite interesting.

1. Students were asked to list the occupations of their fathers. The occupations were classified according to the same Brussel-Barr Scale of Occupational Intelligence (Brussel, 1930) used by Blair. Thirteen percent of the 1938 fathers' occupations fell in the professional categories, while, $76 \%$ of the 1983 fathers did.

2. The educational levels of both groups of parents were considerably higher than the average educational level of the entire population, as revealed by the respective census. Fifty-eight percent of the 1983 groups parents were college graduates, while $10 \%$ of the 1938 group were. Both groups were equal in percentages of high school graduates.

3. The students were asked to list their most liked and disliked school subjects. There were very few differences between the boys of each group. The girls, however, showed several dissimilarities. Approximately $40 \%$ of the 1983 girls chose mathematics and science as their favorite subjects, while only $18 \%$ of the 1938 group did. No girls in the 1983 group chose commercial subjects, whereas almost $15 \%$ of the 1938 group of females did. 
4. The comparisons of hobbies between the two groups also revealed some interesting changes. Reading, as a hobby, was quite high on the list of the 1983 group and was surprisingly 5\% higher than the 1938 students. This indicates that an increase in reading, as a hobby, has taken place. This fact seems contrary to the popular opinion of reading habits of today's youth. Even more surprising was the fact that no 1983 student listed TV watching as a hobby.

5. A greater percentage of the 1983 students plan to go on to college, a change from $60 \%$ in the 1938 study to $90 \%$ in the 1983 study was found in the boys. The statistics for the girls, once again were more dramatic; the percentage more than doubled, going from $45 \%$ in 1938 to over $98 \%$ in 1983.

6. The occupational choices too have changed. Forty-five percent of the boys from 1938 chose a professional occupation as a career compared to $94 \%$ of the 1983 boys. Four times as many girls from the 1983 group chose professional occupations as did the 1938 group of gifted/talented females.

Part II

The second part, the comparisons between the 1983 groups of artistically talented and academically gifted junior high school students was of great interest to me as an art educator. It has often been said that great differences exist between academically and talented groups of students. My findings showed that many more similarities existed than differences between the two groups. Comparisons were not made between the males and females because the population of each group would have been too small and would not have given a useful indication of patterns or trends.

1. The occupational levels of fathers were equally matched for both the academic and talented groups. The mothers, occupational levels, though slightly lower than the fathers, were also evenly distributed between the two groups.

2. The educational levels of the academic group's fathers had $10 \%$ more college graduates than did the arts group and the fathers of both groups was less than $10 \%$ higher than that of the mothers of both groups.

3. The number of siblings in each of the group's families were nearly identical. Most students had one brother or sister. The next most common occurence was 2 brothers or sisters. Only one percentage point separated the number of students that were an only child in each group.

4. Approximately $54 \%$ of the academically gifted students chose math, science, and computers as their favorite school subjects, while only $36 \%$ of the arts group did. Thirty-six percent of the arts group, however, chose art as their favorite subject, while none of the academic group chose art. Neither group chose physical education as a favorite subject.

5. The questionnaire also asked, "which subject do you dislike the most". A sort of reversal took place when their most disliked subjects were compared with their liked subjects. The academic group disliked math and science more often than did the arts group. Math was disliked the most by both groups, 
followed by English. Physical education was the fourth most disliked subject by both groups, yet sports as a hobby and school extra-curricula activities was very high in both groups.

6. Both groups of students were involved in many school extra-curricular activities. The questionnaire really only allowed room for one or two acitivites to be listed, however the majority of the students listed three or more. Sports was the highest in both groups making up almost $40 \%$ of each groups choices. Music was the second highest in both groups and surprisingly higher in the academic group. Clubs were the third most reported achool activity. A large portion of the arts groups involvement in clubs was membership in an art club.

7. Both groups also seem very involved with hobbies. Once again not much room was provided on the answer form for listing hobbies, yet many students continued to list hobbies on the back of the form. Sports, reading, fantasy game playing, and collecting were popular in both groups. Art was also very popular in the talented group, however, it did place second to sports. I was pleasantly surprised to see that $5 \%$ of the academic group chose art as a hobby and I was not expecting to find the academic group choosing music, drama, and dance more often than the art group.

8. The students were asked to list two books that they enjoyed reading. The academic group chose books that could be termed classics, while the arts group preferred teen and children's books. Both groups frequently listed science fiction books. The most popular books in both groups were: Hobbitt Lord of the Flies, and Lord of the Rings.

9. The ambitions of the two groups, regarding educational and career goals, were quite high. Most students seemed to have established at this early age specific objectives. Over $90 \%$ of each group were planning to attend college. A higher percentage of both groups wanted to take courses in law, medicine, and science. Thirty-one percent of the arts group planned to take art courses, particularly computer graphics. None of the academic group indicated plans to take art courses. The two groups were evenly matched in choosing engineering and science, while the arts group was $20 \%$ higher in choosing computer courses.

10. The occupational ambitions of both groups were equally high. More than $75 \%$ of each group knew what occupation they expected to follow as a life's career. Both groups showed a preference for professional and semiprofessional occupations. These two categories accounted for $97.1 \%$ of the academic group and $93.8 \%$ of the arts group.

My major conclusions so far for both parts of the study are that:

1. Major differences exist between the gifted and talented youth of today compared to those of 45 years ago.

2. There do not appear to be as many differences between the academically gifted and artistically talented in the 1983 group. Their backgrounds, interests, and ambitions appear to be similar. 
with students from 1938 than there were between the arts and academic groups of 1983.

\section{REFERENCES}

Blair, G.M. (1938). Mentally superior and inferior children in the iunior and senior high school. New York: Bureau of Publications Teachers College, Columbia University.

Brussel, E.S. (1930). A study of the composition of juries of the district court. Thesis, University of Minnesota, Minneapolis, MN.

Hollingworth, L.S. (1926). Gifted children: their nature and nurture. New York: Macmillan Co.

Hollingworth, L.S. (1935). Comparative beauty of the faces of highly intelligent adolescents. Journal of Genetic Psychology, 47, 268-281.

Terman, L.M. (1925). Genetic studies of genius Vol. 1. Mental and physical traits of a thousand gifted children. Stanford, CA: Stanford University press. 